\title{
An introduction to neglected disasters
}

Ben Wisner

Aon-Benfield Hazard Research Centre, University College London, UK Environmental Studies Program, Oberlin College, USA

bwisner@igc.org

JC Gaillard

UMR 5194 Pacte - CNRS, Université de Grenoble, France Department of Geography, University of the Philippines Diliman Jean-Christophe.gaillard@ujf-grenoble.fr

\section{Introduction}

This theme issue of Jàmbá takes up the question of neglected disasters. It is an important topic because the world is changing, disasters are changing, and theory is changing. All these changes call for a re-assessment of why some human suffering and social disruption receive attention from authorities, donors, researchers and the media, while some does not. Recent progress in both development studies and disaster studies provides tools for answering this question. Development and disaster studies date in their current forms to ways of thinking that were current in academic and policy circles in the late 1950s and 1960s. At that time the world was recovering from world war and former colonies of Europe were gaining independence. It was a world in which (with some exceptions) conflict was held in check in an uneasy cold war balance. It was also a world where a growing $\mathrm{UN}$ system held the promise of meeting humanitarian needs when they arose. That world is no more. 'Development' has changed. Today former colonial states have differentiated at two extremes: failed states and middle income developing ones. Super power balance is no more, and many local and regional conflicts rage. The United Nations system is stretched to breaking point by economic recession. All of this affects the range and nature of crises facing ordinary people and how these crises are perceived by outsiders.

Disasters are also changing. Even natural events that seem straightforward, such as floods or volcanic eruptions, may be made complex and more damaging because of conflict situations and extreme polarity between rich and poor. The displaced and marginalized in this 'new world disorder' are denied the tools to protect themselves. So, for example, in the final days of the assault of government troops on the Tamil Tigers in Sri Lanka, people displaced by fighting found themselves also facing floods. When a nearby volcano erupted in 2002 and split the 
eastern Democratic Republic of Congo city of Goma in two with fast flowing lava, an insurgent army was in charge and provided no warning or assistance to fleeing people. Climate instability, environmental degradation, and urbanization all have added new categories of vulnerable people and livelihoods to the lexicon of disaster risk.

So, too, as noted above, theory underlying development and disaster studies is changing. In the 1950s and 1960s disasters were seen as synonymous with hazards. Extreme natural events were the secular equivalent of 'acts of god.' Structural engineering approaches were invoked as a way of taming nature; dams, irrigation projects, anti-seismic construction, levies, and coastal protection were seen as the solution. In the 1980s and 1990s a different framework developed. Disasters came to be seen as a dysfunction or failure of development, as a symptom of maldevelopment and symptom of the accumulation of contradictions and tensions due to failed development. In this new framing, society itself was seen to put various groups of people at risk by decisions made by the market place or by people with political power. Extreme natural events became viewed as triggers, not fundamental causes or drivers. The first decade of the $21^{\text {st }}$ Century has seen more developments in the way that disasters are theorized in the context of development (and vice versa). In addition to the social origin of root causes (issues of access to resources and marginality), growing concern with climate change has re-introduced nature into disaster studies and development studies. However, this time around, nature is understood differently than it was in the 1950s and 1960s, at least by a significant and growing number of scholars and policy makers. Nature is not an autonomous cause of disaster, but is part of a complex society-nature system that shares out costs and benefits, causes and effects unevenly among nations and within nations (by class, gender, ethnicity, region, etc.). At each stage in the development of thinking about disaster, more and more phenomena have had to be integrated. This intellectual complexity and inclusiveness is mirrored in an emerging policy consensus that poverty reduction, climate change adaptation and risk reduction have to be pursued as a comprehensive whole.

But such a comprehensive approach to development and disaster implies that previously - and currently - neglected forms of threat, misery and disruption must be taken into account. As the optics for viewing disaster have changed, so has understanding of what must not be excluded or neglected if a comprehensive approach is to be realised. What, then, has been neglected that must now become part of the discussion? The papers in this theme issue present a variety of disastrous situations that have been neglected in different ways and for different reasons. All the papers were presented at the first World Conference on Humanitarian Studies held in February, 2009, in the Netherlands.

\section{Which disasters are neglected and why?}

\section{What's neglected?}

Magnitude (measured in deaths, financial impact, etc.) has something to do with the degree of attention and assistance given to a situation that demands more than local, sub-national, or national resources and capacities. The Asian tsunami, the Kashmir earthquake, the cyclone that affected Burma and the Haiti earthquake all clearly fall into the largest magnitude and most 'visible' category of disaster. 
At the other extreme, researchers in Latin America have used a data base called DesInventar to catalogue for Colombia alone more than 19,000 small and moderate events that took lives,

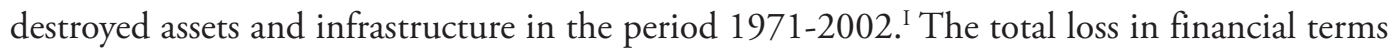
was greater than all of the high profile disasters to affect that country taken together, including the deadly eruption of Nevado del Ruiz in 1985. The best known international data base, EMDAT, of the Centre for Research on the Epidemology of Disasters, records only 97 disasters in Colombia for that period. Few of these 19,000 small and moderate events made it into the national press in Colombia, yet alone the world media.

There also seems to be a bias in the media toward the drama of sudden onset disasters such as those linked to earthquakes, tsunamis, volcanic eruptions, coastal storms, and rapidly rising flood waters. Slow onset and pervasive hazards such as drought, desertification, coastal erosion, collapse of fisheries are harder to follow from a journalistic point of view, but the livelihoods and life chances of millions are at stake.

\section{Neglected by whom?}

In considering the neglect of some disasters, we also have to consider context and agency. Who is doing the 'neglecting'? We have already mentioned the media. But what is 'the media'? Despite growing economic concentration in some areas, there is great diversity in the communications industry. There are large news services that come to mind and established brands with global reach such as BBC and CNN. Yet, alongside there are also Al Jazeera and Al Jazeera English ${ }^{\mathrm{II}}$ as well as many internet-based news services such as AlertNet ${ }^{\mathrm{III}}$, the web sites of hundreds of non-governmental agencies and specialized lobbies, support networks and research institutions. Also, a good deal of news is transmitted, analysed and debated by professionals and non-professionals on thousands of blogs and social networking sites.

Donors are another group that prioritize disasters and are thus potential agents of neglect. Within the past few years there have been efforts to come up with common assistance criteria and standards under such terms as 'good donorship' and some very successful attempts to do common evaluation of humanitarian action, such as the Active Learning Network for Accountability and Performance in Humanitarian Action - ALNAP. ${ }^{\text {IV }}$ Nevertheless, despite the existence of such standards, national governments make their decisions about where to allocate humanitarian funding based on national interest whether they say so or not. Is it a coincidence that Burma is resource rich and received a great deal of attention when cyclone Nargis struck in 2008; while hundreds of thousands of North Koreans have starved over the past decade in a resource poor country with little attention from the outside? Both countries are highly secretive, closed societies. So they make an informative matched pair.

\section{Neglected when?}

Timing plays a big role in two ways. Several large and equally compelling humanitarian disasters taking place at the same time may end up with one casting the other in its shadow. The Asian tsunami had that effect on the food crisis in Niger, West Africa, in 2004-2005. Hurricanes Katrina and Rita over-shadowed hurricane Stan and the death and destruction it pro- 
duced in Guatemala later in 2004-2005 hurricane season. A paper in this theme issue of Jàmbá deals with this shadow effect. Djindil and de Bruijn discuss how extreme poverty and marginality in rural Chad are simply not visible to the caravans of humanitarian aid workers travelling through en route to the East of Chad, where the plight of refugees displaced from Darfur occupies their attention.

The second temporal issue is duration. The media and the public tire eventually of telling and hearing the 'same' story. Donors and NGOs are concerned with budget cycles, log frame results, and exit strategies. Some humanitarian emergencies seem never-ending: violence, rape, displacement and disease in the Democratic Republic of Congo, the civil war in Colombia, the combination in Haiti of violence, misrule, environmental degradation, poverty, floods, drought and landslides. Some seem to recur every few years: cycles of flood, drought and food emergency in much of southern Africa, for example. Still others have no clear end point. The paper in this issue on refugee women displaced from Western Sahara discusses a protracted disaster that has fallen off the agenda of most media and agencies because it is so protracted.

Recovery is a common word, but as a process, it is very poorly understood. When will post hurricane Katrina New Orleans 'recover', or the city of Bam in Iran that suffered a huge earthquake in 2003? In the sense of rebuilding, it is possible to identify a time horizon. But full economic, environmental, cultural and psycho-social forms of recovery take longer, are variable, and in some cases may never happen. The cameras and most of the aid workers have left a long time before any of this takes place.

\section{Why neglected?}

There is no single reason. There is some self-interest among NGOs at work, perhaps even some cherry picking and competition for a role where it is easier to get attention for one's agency's good works and thus more support. More charitably, we might say that NGOs often find it easiest to work where they have people on the ground, some history, or good partners. National interest is also at work to some degree. The U.S. was keen to send aid to post-earthquake Pakistan and post-tsunami Indonesia as a way of improving its image in the Islamic world. That is not to say that the humanitarian ethic is a sham. It has coexisted for many years with political and economic self-interest. The current spate of publications about 'disaster capitalism' do not deny the legitimacy of an ethic based on universality, humanity, and neutrality, but show how such principles and their application must navigate the neo-liberal world of self-interest and markets (Klein, 2005; 2007; Gunewardena \& Schuller, 2008).

Other disasters are neglected because they are misunderstood. This is a very important reason for neglect, and one we take up in more detail in the next section of this introduction. If donors, NGOs, the media, and the public understood the full cost in social and economic terms of the small and moderate events that punctuate the lives of the poor and marginal around the world, more attention would be paid to them. People whose lives are chronically unstable because of the occurrence of many small and moderate hazard events are less likely to adapt to climate change in place. They may become displaced. They are already the ones most likely to end up in poor (and dangerous) parts of growing cities - even before the most severe impacts of climate change. 
Some disasters fall between stools, are misclassified, or just not counted. One example is the illegal dumping of a whole cargo boat load of hazardous waste in the suburbs of Abidjan, Ivory Coast in 2006. ${ }^{\mathrm{V}}$ Thousands of people became ill. This was a huge disaster that nearly toppled the government. However, it was neither seen as a 'natural' disaster nor a 'technological' disaster. Very little follow-up has been done by media or development organizations. What has happened to the people who became ill? What are the chronic effects? Are these people working? Are their families coping? Are their children in school? Charles Kelly's paper on Tajikistan in this issue of Jàmbá discusses such a compound disaster, one that falls between categories.

\section{From everyday neglect to disasters}

Neglect is not limited to perception of the salience of specific events. As we just discussed, neglect extends to the understanding of and attention to the issue of why people suffer as well as who suffers from disasters and who does not. This is true on different scales. On the global scale, countries most affected by disasters, both in terms of human losses and economic damage as proportion to Gross Domestic Product (GDP), are those with low and low-middle income, which simultaneously experience rapid economic growth (United Nations International Strategy for Disaster Reduction, 2009). Small island developing states and land-locked developing countries which play a marginal economic and political role on the international scene, are among the most affected (concerning land-locked states see Kelly's paper on Tajikistan and the treatment of Chad by Djindil and de Bruijn in this issue of Jàmbâ). On the local scale, people affected by disasters are chiefly members of neglected segments of society, i.e. the most marginalized social groups, including the poor but also women, children, the elderly and disabled people, illegal immigrants, prisoners, refugees, and members of ethnic and religious minorities.

Chronic daily neglect by those with social, economic and political power leads to fragile livelihoods for people who are exposed to natural hazards. In this theme issue of Jàmbá, van Voorst shows how poor families in Greenland that rely on hunting to make a living are disadvantaged in the face of the impact of climate change compared to richer households with a larger range of hunting implements and resources. Gaillard and Cadag similarly document how weak and limited livelihoods have forced marginalized Filipino people to live at the foot of a dangerous dumpsite near Manila without adequate resources to protect themselves. They also show that poor livelihoods and political neglect have further hindered their ability to recover in the aftermath of a disastrous mass movement of compacted solid waste, thus leading to further marginalisation. The recent Global Assessment Report on Disaster Risk Reduction prepared by the United Nations International Strategy for Disaster Reduction (2009) provides many more examples of such inequality in disaster losses in both rural and urban settings.

Neglect is also manifested by institutional and operational ignorance of locally available means of protection. The fact that in every disaster, damage is unevenly distributed, that some survive while others die, that some buildings collapse when others stand, shows that avoiding harm is possible. This is true in both affluent and less affluent countries. In Aceh, Indonesia, 70\% of the victims of the late-2004 tsunami were women; while records from the heat wave, which 
struck France in 2003 show that 64\% of those who died were female (Oxfam International, 2005; Poumadère et al., 2005). Despite such documentation over the years, policy makers do not address the root causes that underlie such stark differential social impacts.

On the national scale, ultimately, disasters reflect neglect of vulnerable groups by national economic and political elites and poor governance. Too many disasters are indeed rooted in the non-respect of existing construction codes, the misuse of public funds, or the looting of natural and economic resources to the benefit of the most powerful (e.g. Wisner, 2001; Lewis, 2008; Gaillard et al., 2007).

One could speak of 'neglect of neglect' when donors and international institutions turn a blind eye to political neglect of marginal groups of people, dwelling instead on the trappings of 'democratic process' under the rubric of 'good governance.'

\section{Neglecting opportunities for partnership}

Poor governance and political neglect leave opportunities for change and sustainable disaster risk reduction untapped. Nobody is more interested in reducing disaster risk than the communities whose survival and well-being is at stake, and no one knows better the local conditions of vulnerability than disaster victims themselves. In theory government administrations at the local level could tap such local knowledge and build partnerships for disaster reduction. Many studies emphasize the capacities of local communities to face natural hazards on their own should they be empowered with adequate resources (e.g. Anderson \& Woodrow, 1989; Delica-Willison \& Willison, 2004). Such capacities include accurate and detailed knowledge of natural hazards and long-tested, culturally-sensitive indigenous coping strategies. In the aftermath of the powerful 2004 earthquake which occurred off the coast of the small island of Simeulue in Indonesia, locals immediately sought refuge in defined areas in the surrounding mountains and survived the eventual tsunami which killed almost 170,000 people along the coast of the neighbouring island of Sumatra (Gaillard et al., 2008). Sadly, such accounts are not new stories emerging from recent cutting-edge research. As early as in the late 1970s, Wisner et al. (1977) referred to the "untapped power of people's science" to emphasize how local knowledge and capacities are wasted when experts advocate only top down measures.

A report by the Global Network of Civil Society Organisations for Disaster Reduction (2009) reflects the frustration of civil society leaders and non-governmental organisations (NGOs). Based on 7,000 interviews with local people in 48 countries, the report shows that the United Nations' Hyogo Framework for Action for Disaster Reduction (United Nations International Strategy for Disaster Reduction, 2005) is not 'trickling down' in operational terms. The report suggests that "the key to unlocking ... local resources is through adopting participatory approaches - civil society, particularly grassroots women's groups, can play a critical role in facilitating this community engagement". The present theme issue of Jàmbá also offers evidence that disaster victims are able to fight back and that this ability is often overlooked by technocratic and command-and-control policies and policy makers. Amorim details the resistance of a Brazilian community which was forced to relocate to give space for the construction of a large dam. Eventually, the displaced people were able to rebuild their lives and memorialise their 
original town despite government's failure to provide appropriate social and economic opportunities. Belloso and Azkue describe the situation of Sahrawi women, marginalized within their society and affected also by an internationally forgotten conflict that has made them refugees. The authors demonstrate women's crucial role in developing individual and collective capacities to cope with the harsh living conditions they face in protracted refugee camps in Algeria. In Chad, conflict in Darfur across its eastern border has skewed the attention of international media and aid agencies that focus on refugees in Chad to the exclusion of Chadians themselves who are locally both threatened by natural hazards and fighting between the N'Djamena government and rebel forces. Djindil and de Bruijn show that the local communities, which have to cope with the violence related to the local Chadian conflict and recurrent drought episodes, manage to make a meagre living from the scarce available resources and without much assistance from the outside.

The stories of pain and struggle in the context of disasters and armed conflicts presented in this volume militate for a critical shift in the position of those usually neglected in development and disaster risk reduction policies. The acuity of their needs, their knowledge and their skills compel one to consider them as primary active stakeholders rather than marginalized and helpless victims.

\section{References}

ANDERSON, M. and WOODROW, P. 1989. Rising from the Ashes: Development Strategies in Times of Disasters. Boulder: Westview Press.

DELICA-WILLISON, Z. and WILLISON, R. 2004. Vulnerability reduction: A task for the vulnerable people themselves. (In Bankoff, G., Frerks, G. and Hilhorst, D. eds. Mapping vulnerability: Disasters, development and people. London: Earthscan.)

GAILLARD, J.-C., LIAMZON, C.C. and VILLANUEVA, J.D. 2007. 'Natural' disaster? A retrospect into the causes of the late-2004 typhoon disaster in Eastern Luzon, Philippines. Environmental Hazards, 7(4):257-270.

GAILlARD, J.-C., ClAVE, E., VIBERT, O., AZHARI, DEDI, DENAIN, J.-C., EFENDI, Y., GRANCHER, D., LIAMZON, C., SARI, D.R. and SETIAWAN, R. 2008. Ethnic groups' response to the 26 December 2004 earthquake and tsunami in Aceh, Indonesia. Natural Hazards, 47(1):17-38.

GLOBAL NETWORK OF CIVIL SOCIETY ORGANISATIONS FOR DISASTER REDUCTION. 2009. "Clouds but Little rain..." - Views from the frontline: A Local Perspective of Progress towards Implementation of the Hyogo Framework for Action. Teddington: Global Network of Civil Society Organisations for Disaster Reduction. Available at http://www.globalnetwork-dr.org/reports/ VFLfullreport0609.pdf

GUNEWARDENA, N. and SCHULLER, M. eds. 2008. Capitalizing on catastrophe: Neo-liberal strategies in disaster recovery. Lanham, MD: Alta Mira Press.

KLEIN, N. 2005. The Rise of Disaster Capitalism. The Nation, 14 April 2005

http://www.thenation.com/doc/20050502/klein. 
KLEIN, N. 2007. The Shock Doctrine: The Rise of Disaster Capitalism. New York: Metropolitan Books.

LEWIS, J. 2008. The worm in the bud: Corruption, construction and catastrophe. (In Bosher, L. ed. Hazards and the Built Environment: Attaining Built-In Resilience. London: Routledge).

OXFAM INTERNATIONAL. 2005. The Tsunami's Impact on Women. Oxfam Briefing Note, Oxford: Oxfam International.

POUMADERE, M., MAYS, C., LE MER, S. and BLONG, R. 2005. The 2003 heat wave in France: Dangerous climate change here and now' Risk Analysis 25(6):1483-1494

QUARANTELLI, E.L. and DYNES, R.R. 1972. When disaster strikes: It isn't much like what you've heard \& read about. Psychology Today, 5(9):66-70.

UNITED NATIONS INTERNATIONAL STRATEGY FOR DISASTER REDUCTION. 2005. Building the Resilience of Nations and Communities to Disaster: An Introduction to the Hyogo Framework for Action. Geneva: United Nations International Strategy for Disaster Reduction. Available at http://www.unisdr.org/eng/hfa/docs/HFA-brochure-English.pdf

UNITED NATIONS INTERNATIONAL STRATEGY FOR DISASTER REDUCTION. 2009. Risk and Poverty in a Changing Climate: Invest Today for a Safer Tomorrow - 2009 Global Assessment Report on Disaster Risk Reduction. Geneva: United Nations International Strategy for Disaster Reduction. Available at http://www.preventionweb.net/english/hyogo/gar/report/index.php?id=9413

WISNER, B. 2001. Changes in capitalism and global shifts in the distribution of hazard and vulnerability. (In Pelling, M. ed. Natural disasters and development in a globalizing world. London: Routledge.)

WISNER, B., O'KEEFE, P. and WESTGATE, K. 1977. Global systems and local disasters: The untapped power of peoples' science. Disasters, 1(1):47-57.

\footnotetext{
Notes

I. http://www.desinventar.org

II. http://english.aljazeera.net/NR/exeres/55ABE840-AC30-41D2-BDC9-06BBE2A36665.htm

III. www.alertnet.org

IV. http://www.alnap.org/

V. http://www.nytimes.com/2006/10/02/world/africa/02ivory.html \&

http://www.guardian.co.uk/world/2009/sep/16/trafigura-african-pollution-disaster.
} 